\title{
SEJARAH SOSIAL-BUDAYA KABUPATEN KUNINGAN
}

\section{SOCIAL-CULTURAL HISTORY OF KUNINGAN REGENCY}

\author{
Euis Thresnawaty $\mathbf{S}$. \\ Balai Pelestarian Nilai Budaya Jawa Barat \\ Jl. Cinambo 136 Ujungberung Bandung. \\ email: euisthresnawaty62@gmail.com
}

Naskah Disetujui:23 Februari 2016

\begin{abstract}
Abstrak
Kuningan adalah salah satu kabupaten di Provinsi Jawa Barat yang terletak di ujung Timur. Dari sisi sejarah sosial budayanya Kabupaten Kuningan menarik untuk dikaji, karena sejak beberapa abad yang lalu daerah Kuningan telah menjadi daerah pemukiman manusia. Dari penemuan-penemuan benda seperti menhir, dolmen, dan lain-lain dapat disimpulkan bahwa daerah Kuningan telah didiami oleh manusia sejak masa neolitik. Namun demikian, mengingat panjangnya sejarah yang dilalui Kabupaten Kuningan dengan melalui beberapa masa maka penelitian ini difokuskan pada masa kolonial hingga kemerdekaan untuk mengetahui bagaimana kondisi sosial budaya di Kabupaten Kuningan pada masa tersebut. Metode yang digunakan adalah metode sejarah yang meliputi heuristik, kritik, interpretasi, dan historiografi. Hasil penelitian menunjukkan bahwa sejak dahulu posisi Kabupaten Kuningan yang strategis membuat wilayah dan masyarakatnya senantiasa mampu mengikuti dinamika kehidupan, sehingga memungkinkan terjadinya interaksi dengan kelompok masyarakat lainnya baik secara teritorial maupun kultural.
\end{abstract}

Kata kunci: Sejarah sosial, Kabupaten Kuningan.

\begin{abstract}
Kuningan District is one area in West Java province located at the end of Northeast. In terms of social and cultural history of Kuningan regency, it is interesting to be investigated since from several centuries ago Kuningan has become the area of human settlements. From the discoveries of objects such as menhirs, dolmen, etc, it can be concluded that the Kuningan has been inhabited by humans since the Neolithic era. Nevertheless, due to the long history of Kuningan, this study only focused on the colonial to independence period to determine how the social and cultural conditions in the district of Kuningan in that era. The method used is the historical method which includes heuristics, criticism, interpretation, and historiography. The results showed that from long ago, the strategic position of Kuningan District makes this area and the community is able to follow the dynamics of life, thus it enables the interaction with other community, both territorially and culturally.
\end{abstract}

Keywords: social history, Kuningan regency.

\section{A. PENDAHULUAN}

Penulisan sejarah suatu daerah sangat diperlukan karena dapat memenuhi keinginan atau hasrat untuk mengetahui dan memahami masa lampau atau sejarah daerah tempat tinggal dan daerah asal kita.
Selain itu juga untuk mengetahui asal usul budaya, dan untuk mengerti serta memahami pengetahuan tentang perkembangan suatu daerah. Pengetahuan ini tentu sangat diperlukan agar tidak terjebak dalam pengulangan kesalahan 
yang telah dilakukan pada masa lampau serta dapat menumbuhkan kesadaran akan identitas kita. Sejarah juga dapat berfungsi sebagai media untuk menumbuhkan rasa cinta terhadap tanah tumpah darah dan rasa solidaritas sosial (Thresnawaty, 1995:1).

Sementara itu terjadinya perubahan sosial budaya adalah sebuah gejala berubahnya struktur sosial dan pola budaya dalam suatu masyarakat. Perubahan dalam sosial dan budaya merupakan gejala umum yang terjadi sepanjang masa dalam setiap masyarakat. Perubahan ini terjadi sesuai dengan hakikat dan sifat dasar manusia yang selalu ingin melakukan perubahan. Tiga faktor yang dapat memengaruhi perubahan sosial adalah tekanan kerja dalam masyarakat, keefektifan komunikasi, dan perubahan lingkungan (Sulistiyani, 2011: 124). Perubahan budaya juga dapat timbul akibat perubahan lingkungan masyarakat dan kontak dengan kebudayaan lain.

Sementara itu dari sisi sejarah, sejarah sosial mempunyai garapan yang sangat luas dan beragam. Banyak sejarah sosial yang berhubungan dengan sejarah ekonomi sehingga menjadi sejarah sosialekonomi atau yang berhubungan dengan budaya, maka menjadi sejarah sosialbudaya. Di negara-negara yang sedang berkembang seperti Indonesia, kegiatan penelitian dan penulisan sejarah sosial masih sedikit terutama yang bercorak sejarah sosial daerah.

Sekalipun sejarah sosial sudah merupakan gejala baru dalam penulisan sejarah sejak sebelum Perang Dunia II, tetapi sebagai sebuah gerakan yang penting baru mendapat tempat sekitar tahun 1950an. Di Perancis aliran penulisan Annales yang dipelopori oleh Lucien Febvre dan Marc Bloch menjadi modal bagi generasi baru penulis sejarah sosial yang semakin kuat kedudukannya dalam dunia penulisan sejarah (Kuntowidjojo, 1999: 39).

Kajian Sejarah sosial-budaya di Kabupaten Kuningan menarik untuk dikaji karena beberapa faktor, di antaranya adalah Kabupaten Kuningan adalah sebuah wilayah yang berada di bagian Timur Provinsi Jawa Barat. Kabupaten ini memiliki rentang sejarah yang cukup panjang dan erat kaitannya dengan proses penyebaran agama Islam yang dilakukan dari Cirebon. Oleh karena itu, perjalanan sejarah Kuningan dan bahkan awal mula munculnya nama "Kuningan" sangat erat kaitannya dengan Cirebon. Meskipun demikian, jauh sebelum masuknya pengaruh Islam di daerah ini telah terdapat komunitas masyarakat dalam bentuk pemerintahan. Setelah masuknya Islam daerah ini kemudian menggunakan nama Kuningan sebagai identitas daerah.

Selain itu ada hal menarik lainnya, yaitu dari posisi lokasi geografis Kabupaten Kuningan. Wilayah ini berada pada lintasan transportasi multiarah. Wilayah-wilayah yang berada di sekitar wilayah Kabupaten Kuningan adalah:

1. Wilayah Kabupaten Ciamis di sebelah Selatan

2. Wilayah Kabupaten Cirebon di sebelah Utara

3. Wilayah Kabupaten Majalengka di sebelah Barat

4. Wilayah Kabupaten Brebes di sebelah Timur

Lintasan multiarah seperti itu selain terjadinya mobilitas manusia dan barang tentu tidak bisa dihindari adanya pengaruh nilai-nilai kehidupan sosialbudaya memasuki wilayah dan masyarakat Kuningan, antara lain:

1. Nilai kehidupan sosial-budaya dari arah Timur, yaitu wilayah Jawa Tengah.

2. Nilai kehidupan sosial-budaya dari arah Utara, yaitu Cirebon atau lebih luas lagi nilai budaya Jalur Pantura (pantai utara).

3. Nilai kehidupan sosial-budaya Bumi Parahyangan dari arah Selatan. Dari arah Priangan Barat (Bogor, Sukabumi, Cianjur), Priangan Tengah (Bandung Raya dan Sumedang), Priangan Timur (Garut, Tasikmalaya, Ciamis).

Namun dari ketiga wilayah tersebut yang paling dominan adalah pengaruh dari wilayah Bumi Parahyangan, 
budaya khas etnis Sunda (Mutakin, 2005:3).

Dampak positif dari keberadaan wilayah yang strategis seperti ini adalah keterjangkauan dari daerah-daerah sekitarnya menjadi relatif sangat mudah. Kondisi daerah seperti itu dapat menghindarkan wilayah dan masyarakat Kabupaten Kuningan dari kondisi yang terisolasi baik secara teritorial maupun kultural, sehingga wilayah dan masyarakat Kuningan mampu mengikuti dinamika kehidupan.

Dalam mengkaji permasalahan yang akan dibahas digunakan literatur terdahulu sebagai sumber rujukan dalam penelitian ini. Dari sejumlah sumber tertulis mengenai Kabupaten Kuningan terdapat beberapa buku yang dapat djadikan sumber acuan yang saling melengkapi. Buku pertama adalah "Sejarah Kabupaten Kuningan" karya Tim Pusat Studi Sunda dengan ketua Edi S Ekadjati yang terbit taun 2003. Buku ini membahas sejarah Kabupaten Kuningan dari masa prasejarah hingga reformasi.

Sumber tertulis kedua adalah buku yang berjudul "Kuningan Menembus Waktu” yang dikeluarkan oleh Pemda Kuningan tahun 2000. Buku ini membahas mengenai sejarah, kesenian, dan kuliner. Sumber ketiga adalah hasil penelitian dari Ani Rostiyati dkk. tahun 2008 berjudul "Peta Kebudayaan Indonesia, Kabupaten Kuningan, Provinsi Jawa Barat” yang membahas tentang profil dan budaya Kabupaten Kuningan.

Permasalahan yang muncul dalam penelitian ini adalah bagaimana kondisi sosial-budaya di Kabupaten Kuningan pada masa kolonial sampai masa kemerdekaan, Adapun tujuan dari penelitian ini adalah mendeskripsikan secara singkat mengenai keadaan sosialbudaya di Kabupaten Kuningan dengan harapan dapat memperoleh gambaran tentang kehidupan mereka saat ini dengan latar belakang masa lalu.

\section{B. METODE PENELITIAN}

Penelitian ini menggunakan metode sejarah yang meliputi empat tahap: heuristik, kritik, interpretasi, dan historiografi. Heuristik yaitu tahap mencari dan menemukan sumber, baik sumber primer maupun sekunder. Untuk mendapatkan sumber tersebut peneliti langsung ke lapangan mendatangi instansi terkait yaitu Dinas Pendidikan dan Kebudayaan Kabupaten Kuningan, Perpustakaan Daerah Kabupaten Kuningan, Badan Pusat Statistik dan lainlain. Selain itu dilakukan wawancara dengan beberapa tokoh. Langkah berikutnya adalah melakukan kritik sumber untuk mengetahui apakah sumbersumber tersebut valid dan dapat dipercaya. Sumber-sumber dikritik baik ekstern maupun intern. Langkah berikutnya adalah interpretasi, merupakan tahap menafsirkan fakta-fakta yang telah terkumpul dengan mengolah fakta yang telah dikritisi dengan merujuk beberapa referensi. Terakhir adalah historiografi yang bertujuan untuk merangkaikan fakta-fakta tersebut menjadi tulisan sejarah.

\section{HASIL BAHASAN \\ 1. Gambaran Umum Kabupaten Kuningan \\ a. Geografi}

Kabupaten Kuningan adalah salah satu daerah di Provinsi Jawa Barat yang terletak di ujung timur laut. Kabupaten Kuningan memiliki luas wilayah 1.195,71 $\mathrm{km}^{2}$ atau 119.571,12 hektar yang terdiri atas pegunungan dan dataran rendah. Daerah pegunungan terhampar di kaki Gunung Ciremai, gunung tertinggi di Jawa Barat, dan daerah dataran rendah tersambung dengan wilayah Kabupaten Cirebon dan Brebes. Secara administratif sebelah barat berbatasan dengan Kabupaten Majalengka, sebelah utara dengan Kabupaten Cirebon, sebelah selatan dengan Kabupaten Ciamis dan Cilacap, sedangkan sebelah timur berbatasan dengan Brebes, Provinsi Jawa Tengah. 
Letak geografis Kabupaten Kuningan berada pada lintasan jalan regional yang menghubungkan Kota Cirebon dengan Wilayah Priangan Timur, dan sebagai jalan alternatif jalur tengah yang menghubungkan BandungMajalengka dengan Jawa Tengah. Sedangkan batas alamnya berupa Gunung Ciremai di sebelah barat, Sungai Cijolang di sebelah selatan, Situ Marahayu di sebelah timur, serta Sungai Cisanggarung dan sebagian jalan Caracas-Sindanglaut di sebelah utara (Kuningan dalam Angka, 2012:5).

Secara administratif pemerintahan Kabupaten Kuningan terbagi menjadi 32 kecamatan, 15 kelurahan, dan 361 desa. Untuk Satuan Lingkungan Setempat (SLS), terdiri dari 33 lingkungan, 1.187 dusun, 1.745 Rukun Warga (RW), dan 5.675 Rukun Tetangga (RT). Ke-32 kecamatan tersebut adalah Kuningan, Darma, Kadu Gede, Nusaherang, Salajambe, Subang, Ciniru, Hantara, Cilebak, Ciwaru, Karangkancana, Jalaksana, Cibingbin, Cibeureum, Luragung, Cimahi, Cidahu, Kalimanggis, Ciawigebang, Sindang Agung, Cipicung, Lebakwangi, Maleber, Garawangi, Cigugur, Kramatmulya, Japara, Cilimus, Cigandamekar, Mandirancan, Pancalang, dan Pasawahan.

Kecamatan berpenduduk terpadat adalah Kecamatan Kuningan dengan kepadatan 3.741 jiwa per $\mathrm{km}^{2}$. Hal ini dapat dipahami karena Kecamatan Kuningan merupakan pusat pemerintahan dan kegiatan ekonomi di Kabupaten Kuningan. Sedangkan kecamatan dengan kepadatan terendah adalah Kecamatan Cilebak dengan kepadatan per $\mathrm{km}^{2}$ hanya 329 jiwa. Kecamatan Cilebak merupakan kecamatan pemekaran dari Kecamatan Subang.

Kabupaten Kuningan yang terletak di antara $108^{\circ} 23^{1}-108^{\circ}$ Bujur Timur dan $6^{\circ} 47^{1}-7^{\circ} 12^{1}$ Lintang Selatan terdiri atas permukaan tanah yang relatif datar dengan variasi berbukit-bukit terutama Kuningan bagian barat dan selatan dengan ketinggian berkisar 700 meter di atas permukaan laut. Bagian timur dan utara memiliki tanah yang semakin rata dengan ketinggian antara 120 meter sampai 222 meter di atas permukaan laut. Pada umumnya daerah ini beriklim tropi s dengan temperatur bulanan berkisar antara $18^{\circ}-32^{\circ}$ serta curah hujan menunjukkan angka rata-rata $2000 \mathrm{~mm}$ sampai $4000 \mathrm{~mm}$ per tahun. Antara bulan September-April terjadi musim hujan, sedangkan pada bulan Mei-Agustus terjadi musim kemarau. Ibukota kabupaten adalah Kota Kuningan.

Daerah Kuningan memiliki banyak sumber air, tetapi kekayaan alam itu lebih banyak dinikmati oleh penduduk luar Kuningan, khususnya penduduk kota dan Kabupaten Cirebon. Empat sumber air di Kabupaten Kuningan yang dimanfaatkan secara komersial oleh berbagai perusahaan di kota dan Kabupaten Cirebon, antara lain:

1. Sumber air tanah di Desa Cipaniis, Kecamatan Mandirancan, yang berdebit 860 liter/detik digunakan Perusahaan Air Minum Kota Cirebon

2. Waduk Darma di Kecamatan Darma berdebit 100 liter/detik, dimanfaatkan Pabrik Gula Tersana di Kecamatan Babakan Kabupaten Cirebon.

3. Untuk memenuhi air kolam renang Ciperna milik pertamina, diambil air dari sumber air tanah Cibulan, Kecamatan Jalaksana.

4. Sumber mata air dari Talaga Remis, Kecamatan Mandirancan, khusus digunakan untuk memenuhi kebutuhan pabrik semen Palimanan, Kabupaten Cirebon, debit airnya 30 liter/detik.

Aliran air tanah di Kabupaten Kuningan pada umumnya mengalir dari barat ke timur. Semakin ke timur dan selatan, air tanah semakin berkurang. Di musim kemarau, kebutuhan air untuk minum dan pertanian di bagian tengah dan timur kabupaten ini dapat diatasi dengan membuat sumur galian, tetapi tidak demikian untuk daerah bagian selatan.

Sementara itu jumlah sungai besar dan kecil termasuk anak sungainya di 
Kabupaten Kuningan ada 43 buah yang telah dimanfaatkan untuk kepentingan perikanan, irigasi dan pengairan sawah, walaupun belum seluruhnya optimal karena masih diperlukan peningkatan teknik pengairannya.

Adapun status jalan raya di Kabupaten Kuningan menurut kondisinya yaitu jalan propinsi sepanjang 102,14 km dalam kondisi baik, jalan kabupaten sepanjang 416,10 km kondisinya baik, jalan desa sepanjang $733 \mathrm{~km}$ kondisinya baik, dan sepanjang $1,951 \mathrm{~km}$ dalam keadaan rusak (Kuningan dalam Angka, 2012:37).

Berdasarkan penelitian, sumber alam yang tersedia cukup potensial ialah jenis bahan galian seperti pasir, dan batu kapur di Kecamatan Luragung, pasir dan batu di Kecamatan Jalaksana, Cidahu, dan Cilimus.

Perjalanan ke Kabupaten Kuningan dapat ditempuh melalui dua jalur, yaitu dari Bandung melalui Kabupaten Majalengka dengan jarak 130 $\mathrm{km}$, sedangkan dari Kota Bandung melalui Kabupaten Cirebon menempuh jarak 170 $\mathrm{km}$.

\section{b. Kependuduk an}

Penduduk merupakan modal dasar pembangunan yang harus dibina dan didayagunakan dengan baik, supaya efektif untuk mencapai tujuan pembangunan. Namun bagi negara berkembang, seperti Indonesia, jumlah penduduk yang besar pada umumnya dapat menjadi masalah, antara lain karena daya dukung ekonomi yang terbatas, tingkat pendidikan dan produktivitas yang rendah, serta penyebaran penduduk dan angkatan kerja yang tidak merata baik secara regional maupun sektoral. Penduduk Kabupaten Kuningan bertambah cukup padat dengan laju pertumbuhan sebesar $1,97 \%$ setahun dalam periode 10 tahun (1971-1980) dan menurun menjadi sebesar $1,27 \%$ pada periode 1980-1990 dan periode 1990-2000 diperkirakan menjadi $0,50 \%$ setahun.
Berdasarkan data hasil registrasi penduduk tahun 2000 dapat diketahui bahwa jumlah penduduk Kabupaten Kuningan adalah 958.753 terdiri dari 437.350 orang laki-laki dan 446.976 orang perempuan. Delapan tahun berikutnya jumlah tersebut telah berubah menjadi 949.452 orang, terdiri dari 470.690 orang laki-laki dan 478.762 perempuan. Pertumbuhan penduduk rata-rata $1,13 \%$ per tahun (Badan Pusat Statistik Kuningan, 2000).

Distribusi dan kepadatan penduduk masing-masing kecamatan dapat kita perhatikan terdapat ketidakseimbangan antara distribusi penduduk dengan luas yang ditempatinya. Hal ini tercermin dari kepadatan penduduknya. Dengan sendirinya kepadatan penduduk yang semakin tinggi akan menyebabkan luas tanah garapan menjadi sempit atau habis sama sekali. Menumpuknya sebagian besar penduduk di beberapa kecamatan tertentu apabila tidak dilakukan pengaturan yang baik, cepat atau lambat akan menimbulkan masalah kependudukan dan masalah sosial lainnya.

Jumlah penduduk Kabupaten Kuningan berdasarkan hasil sosial Ekonomi Daerah (Suseda) tahun 2010 dan menurut catatan Dinas Kependudukan dan Pencatatan Sipil Kabupaten Kuningan tahun 2011 mencapai 1.280 .158 orang, terdiri dari 651.937 laki-laki dan 628.221 perempuan. Laju pertumbuhan penduduk (LPP) sebesar 0,87\% per tahun, dengan sex ratio sebesar 103,8. Maksudnya, penduduk laki-laki jumlahnya lebih banyak dibanding penduduk perempuan (Kuningan dalam Angka, 2012:35).

Peran serta masyarakat dalam pembangunan agama di Kabupaten Kuningan semakin meningkat. Berdasarkan data kependudukan pada tahun 2010 penduduk Kuningan beragama Islam yaitu 939.123 orang, Katolik 7.069 orang, Protestan 1.793 orang, Hindu 28 orang, Budha 375 orang, dan lainnya 3 orang. Adapun jumlah sarana peribadatan adalah: masjid 813 buah, langgar 3.599 
buah, mushola 1.060 buah, gereja 10 buah, vihara 1 buah, dan kuil 1 buah (Kuningan dalam Angka, 2012:51).

Di wilayah Kuningan sampai tahun 1900-an, abad ke-20 belum terdapat sekolah untuk pribumi. Keberadaan pesantren mempunyai peranan penting dalam pendidikan untuk rakyat. Sekolah yang pertama didirikan oleh Pemerintah Hindia Belanda untuk bangsa Indonesia di Kuningan adalah Sekolah Kelas Satu (Eerste Klasse Inlandsche School) pada akhir abad ke-19. Sebagai cikal bakalnya adalah sebuah kursus di Kota Kuningan yang diperuntukkan bagi anak bupati dan para menak. Sebagai persiapan bagi anak bupati untuk menjadi bupati, dan bagi para ningrat untuk menjadi calon pegawai pemerintahan. Pada tahun 1914 Sekolah Kelas Satu diubah menjadi HIS (Hollands Inlandsche School) dengan bahasa Belanda sebagai bahasa pengantar dari kelas satu sampai kelas tujuh

Untuk anak-anak dari kalangan menak dan terletak di kota-kota distrik atau kawedanaan disediakan Sekolah Kelas Dua (Tweede Klasse Inlandsche School). Sekolah Kelas Dua ini sering disebut Sekolah Distrik, sedangkan muridmuridnya masih dari kalangan terbatas, yaitu anak-anak dari kalangan terpandang di kawedanaan dan kecamatan, orangorang desa yang dianggap berhasil, dan para pamong desa. Sekolah Kelas Dua di Kuningan yang pertama berdiri ialah di Kota Kuningan sekitar tahun 1905. Setahun kemudian di Kadugede, Cilimus, Ciawigebang, Luragung, dan Mandirancan.

Pemerintah Hindia Belanda kemudian mendirikan Volk Scholen, sekolah yang didirikan untuk anak-anak desa yang bertujuan membuat anak-anak desa bisa menulis, membaca, dan berhitung. Di Kuningan Sekolah Desa baru dimulai pada tahun 1912.

Saat ini sarana pendidikan masyarakat menunjukkan keadaan yang makin membaik, yaitu Taman Kanakkanak-kanak (TK) 228 buah, PAUD 450 buah, Sekolah Dasar (SD) 671 buah, SLTP
90 buah, SLTA 27 buah, dan Perguruan Tinggi 6 buah (Kuningan dalam Angka, 2012:45). Sedangkan sarana pendidikan agama Islam yaitu Madrasah Ibtidaiyah 82 buah, Madrasah Tsanawiyah 50 buah, Madrasah Aliyah 19 buah, Perguruan Tinggi Islam 2 buah, Pondok Pesantren 379 buah, dan Madrasah Diniyah sebanyak 116 buah. Bagaimanapun sederhananya, pendidikan sangat penting untuk anak Indonesia.

Pembangunan kesehatan pun terus diupayakan mengingat jumlah penduduk terus bertambah dari tahun ke tahun. Pembangunan kesehatan mempunyai tujuan agar semua lapisan masyarakat dapat memperoleh pelayanan kesehatan secara mudah, murah, dan merata. Jumlah Rumah Sakit di Kabupaten Kuningan ada 6 buah, Rumah Sakit Bersalin 1 buah, puskesmas 327 buah, dan posyandu 1.392 buah (Kuningan dalam Angka 2012:42).

Sebagian besar penduduk Kuningan bermatapencaharian petani, lainnya bekerja sebagai pedagang, buruh dan pegawai negeri. Bahasa yang digunakan pada umumnya memakai bahasa Sunda dengan dialek khas Kuningan, tetapi ada sebagian kecil yang menggunakan bahasa Jawa, mungkin ini pengaruh dari Cirebon, Indramayu, dan Brebes (Jawa Tengah).

\section{c. A sal-U sul Nama Kuningan}

Terdapat beberapa versi mengenai asal-usul nama Kuningan berdasarkan tradisi lisan dan legenda. Beberapa di antaranya adalah:

1. Di daerah Ciamis dan Kuningan terdapat cerita legenda yang bertalian dengan bokor, yaitu tempat menyimpan sesuatu di dalam rumah dan sekaligus sebagai barang perhiasan yang terbuat dari logam kuningan. Kedua cerita legenda tersebut menuturkan tentang sebuah bokor kuningan yang dijadikan alat untuk menguji tingkat keilmuan seorang tokoh agama. Di Ciamis, dalam cerita Ciung Wanara, bokor itu digunakan untuk menguji seorang 
pendeta Galuh bernama Ajar Sukaresmi yang bertapa di Gunung Padang. Pendeta ini diminta oleh Raja Galuh yang berkedudukan di Bojong Galuh, Desa Karangkamulyan sekarang yang terletak sekitar $12 \mathrm{~km}$ sebelah timur Kota Ciamis, untuk menaksir perut istrinya yang buncit, apakah sedang hamil atau tidak. Kesalahan menaksir akan berakibat pendeta itu kehilangan nyawanya. Sesungguhnya perut buncitnya karena dipasangi bokor kuningan yang ditutupi kain sehingga tampak seperti sedang hamil. Perbuatan tersebut sebenarnya bertujuan untuk mencelakakan pendeta Ajar Sukaresmi. Dalam menaksir perut istri raja sang pendeta menebak bahwa istri raja itu sedang hamil. Raja gembira mendengar taksiran yang salah tersebut, maka segera saja ia memerintahkan agar pendeta dihukum mati karena tebakannya yang salah. Tapi ternyata istri Raja Galuh benar-benar hamil. Raja pun marah dan spontan menendang bokor kuningan, kuali, dan penjara besi yang berada di sekitar istananya. Bokor kuningan jatuh di sebelah utara, kemudian diberi nama Kuningan, kuali (bahasa Sunda kawali) jatuh di Kawali, sekarang kota kecamatan di Ciamis, dan penjara besi jatuh di Kandangwesi nama tempat di Garut Selatan. Sementara itu dalam Babad Cirebon dan tradisi lisan Legenda Kuningan, bokor kuningan digunakan untuk menguji tokoh ulama Islam Sunan Gunung Jati. Dikisahkan di daerah Luragung, sekarang kota kecamatan sekitar $19 \mathrm{~km}$ sebelah timur Kota Kuningan, Sunan Gunung Jati dipersilahkan untuk menaksir kehamilan istrinya Ong Tien Nio dengan maksud untuk menguji keluhuran ilmunya dan berdampak mempertinggi kedudukan keulamaannya. Menurut salah satu versi cerita masyarakat, ternyata yang dikandung Ong Tien Nio (Rara Sumanding) adalah sebuah bokor.
Untuk mengobati luka hatinya Sunan Gunung Jati mengangkat putra Ki Gendeng Luragung yang masih bayi, seorang bayi laki-laki yang diberi nama Suranggajaya yang selanjutnya dititipkan, dipelihara dan dibesarkan oleh Ki Gedeng Luragung penguasa daerah Luragung. Setelah dewasa bayi itu diangkat oleh Sunan Gunung Jati menjadi kepala daerah Kuningan dengan nama Sang Adipati Kuningan.

2. Bahwa nama Kuningan merupakan salah satu nama wuku. Dalam kebudayaan Hindu dikenal 30 wuku. Kuningan adalah nama wuku ke-12. Wuku tersebut bersama-sama dengan wuku Galungan sampai sekarang selalu dirayakan sebagai hari raya oleh para pemeluk agama Hindu. Menurut berita dari naskah "Carita Parahiyangan", sejak abad ke-8 Masehi ada satu pusat kekuatan politik di Kuningan. Pada saat itu agama Hindu sudah berpengaruh di daerah Kuningan. Hal ini dibuktikan dengan ditemukannya beberapa peninggalan Hindu berupa pecahan batu-batu bekas lingga dan nandi yang terdapat di beberapa wilayah di Kuningan. Penguasa yang memeluk agama Hindu, dan masyarakat pemeluk agama Hindu dapat dipastikan merayakan hari-hari penting seperti "Hari Kuningan" itu.

3. Menurut tradisi lisan lainnya disebutkan bahwa sebelum bernama Kuningan, nama daerah ini adalah Kajene. Kajene mengandung arti warna kuning. Secara umum warna kuning melambangkan keagungan dalam masyarakat Nusantara. Berdasarkan bahan bokor Kuningan dan warna kuning itulah kemudian daerah ini dinamai Kuningan. Namun keotentikan Kajene sebagai nama pertama daerah ini patut diragukan karena menurut Naskah Carita Parahiyangan, sumber tertulis yang disusun di daerah Ciamis pada akhir abad ke-16 Masehi, Kuningan sebagai nama daerah (kerajaan) telah dikenal sejak zaman 
awal Kerajaan Galuh, yaitu sejak akhir abad ke-7 atau awal abad ke-8 Masehi. Sementara itu, wilayah Kerajaan Kuningan terletak di daerah Kabupaten Kuningan sekarang ${ }^{1}$.

Menurut cerita mitologi setempat, nama daerah Kuningan itu diambil dari ungkapan Dangiang Kuning, yaitu nama ilmu atau ajian yang bertalian dengan kebenaran hakiki. Ilmu ini dimiliki oleh Demunawan, salah seorang yang pernah menjadi penguasa di daerah ini pada masa awal Kerajaan Galuh.

\section{d. Pemerintahan}

Seperti telah diuraikan di atas bahwa Kabupaten Kuningan memiliki rentang sejarah yang panjang jika melihat jejak peradaban yang ada. Sejak beberapa abad yang lalu daerah Kuningan telah menjadi daerah pemukiman manusia. Hal ini telah terbukti dengan ditemukannya peninggalan benda-benda arkeologis yang tersebar di seluruh wilayah Kabupaten Kuningan. Peninggalan arkeologi itu terdiri dari alat-alat dan benda-benda yang dibuat dari batu seperti kapak persegi, belincong, menhir, lumpang, dan lain-lain. Berdasarkan penemuan-penemuan tersebut dapat disimpulkan bahwa daerah Kuningan telah didiami oleh manusia sejak masa neolitik. Pada masa itu berkembang suatu kebudayaan yang dikenal dengan kebudayaan megalitik (batu besar) yang merupakan akar kebudayaan Indonesia pada jaman berikutnya (Emran, 1978:13).

Kabupaten Kuningan telah mengalami beberapa masa pemerintahan sejak masa pemerintahan Seuweukarma atau Raja Sangkuku sebagai Raja Kuningan yang pertama. Bahkan pernah dijadikan pusat pemerintahan Kerajaan Sunda di bawah kekuasaan Rakean Darma Siksa, putra Rahiang Banga sebelum dipindahkan ke Pakuan Pajajaran. Pada masa selanjutnya Kuningan menjadi bagian Kerajaan Pajajaran dan namanya

\footnotetext{
${ }^{1}$ https://aditya69.wordpress.com/2007/10/27/sa ng-adipati-kuningan-adalah-putra-luragung/, diunduh 16 Desember 2015
}

diganti menjadi Kajene di bawah kekuasaan Aria Kamuning. Kajene artinya kuning atau emas. Oleh karena itu, daerah ini dikenal dengan nama Kuningan. Pemakaian nama Kuningan ini secara resmi sejak tanggal 11 April 732 Masehi pada masa pemerintahan Aria Kamuning dan terus digunakan hingga sekarang (Emran, 1978: 29).

Sang Adipati Kuningan yang merupakan putra Sunan Gunung Jati adalah kepala daerah pertama yang pengangkatan dan pengesahannya dilakukan oleh Sunan Gunung Jati, sebagai Sultan Cirebon periode 1479-1568. Pelantikan Suranggajaya menjadi Adipati Kuningan diselenggarakan pada tanggal 4 Syura (Muharam). Penanggalan tersebut bertepatan dengan tanggal 1 September 1498 Masehi. Selanjutnya tanggal 1 September ditetapkan sebagai hari jadi Kabupaten Kuningan.

Dengan diangkatnya Sang Adipati Kuningan oleh Sultan Cirebon berarti Kuningan telah memindahkan pengakuan atasannya dari Galuh ke Cirebon. Berarti wilayah kekuasaan Kerajaan Sunda semakin mengecil, sedangkan wilayah kekuasaan Cirebon semakin luas.

Konsep tata kota pusat pemerintahan di Kuningan pun mengikuti tradisi Cirebon, semua kegiatan dipusatkan di sekitar alun-alun. Semua diatur sedemikian rupa sehingga bangunan tempat kegiatan pemerintah (keraton, pendopo, kabupaten) terletak di sebelah selatan alun-alun, pasar sebagai tempat kegiatan perdagangan berada di sebelah utara, penjara sebagai tempat tahanan penjahat letaknya di sebelah timur. Tata kota pusat pemerintahan demikian dijadikan pedoman oleh daerah-daerah di tingkat lebih bawah di lingkungan Kesultanan Cirebon, bahkan sampai tingkat desa. Kecuali ibu kota kabupaten di Kuningan mengalami perubahan pada masa kolonial Belanda. Pendopo kabupaten dipindahkan ke bekas kantor dan rumah dinas Asisten Residen Kuningan yang terletak di bagian utara 
Kota Kuningan. Asisten Residen adalah pejabat kolonial di tingkat kabupaten dalam struktur pemerintahan Kolonial Hinda Belanda. Pada saat ini bekas pendopo kabupaten lama telah dijadikan pusat pertokoan dan perkantoran yang sebelumnya berfungsi sebagai terminal bus dan lapangan sepak bola. Sampai sekarang Pendopo Kabupaten Kuningan tetap menempati bekas bangunan kantor dan rumah dinas Asisten Residen.

Selanjutnya status administrasi pemerintahan keadipatian mengalami perubahan ketika Dalem Mangkubumi meninggal. Hal ini terjadi karena daerah ini menjadi rebutan tiga pusat kekuasaan besar, yaitu Kesultanan Cirebon, Kesultanan Mataram, dan Kompeni Belanda VOC yang berkedudukan di Batavia (Jakarta).

Tahun 1678 Kesultanan Cirebon pecah menjadi Kasepuhan dan Kanoman. Hal ini tentu menimbulkan dampak pada pembagian wilayah kekuasaan. Tahun 1681 Cirebon menyatakan terbuka bagi kedatangan dan kedudukan kompeni melalui perjanjian yang ditandatangani bersama. Secara garis besar daerah Kabupaten Kuningan terbagi menjadi dua wilayah administrasi pemerintahan. Bagian Barat daerah Kuningan masuk ke dalam wilayah Kesultanan Cirebon (Kasepuhan) dan bagian timurnya masuk ke dalam wilayah Gebang yang sudah berdiri sendiri, lepas dari Cirebon. Kedua wilayah administrasi pemerintahan tersebut dibatasi oleh Sungai Japura dan Sungai Cisadane (Ekadjati, 2003:72).

Pada awal abad ke-19 Cirebon telah sepenuhnya berada di bawah Pemerintahan Kolonial Hindia Belanda. Sistem pemerintahan di wilayah Cirebon tampak jelas setelah keluarnya peraturan pemerintahan yang terbit tanggal 2 Februari 1809, Reeglement op het beheer van Cheribonsche Landen (peraturan tentang pemerintahan di wilayah Cirebon) atas prakarsa Gubernur Jenderal Herman Daendels (1808-1811). Bahwa Keresidenan Cirebon yang dibentuk tahun
1705, dibagi menjadi dua prefektur (wilayah administratif setingkat keresidenan), yaitu Prefektur Cirebon, dan Prefektur Priangan-Cirebon. Bagian utara disebut wilayah Prefektur Cirebon meliputi daerah-daerah Cirebon, Kuningan, Indramayu dan Gebang. Bagian sebelah selatan yang disebut Prefektur PrianganCirebon (Cheribonsche Preanger Landen) meliputi kabupaten-kabupaten: Limbangan, Sukapura, dan Galuh.

Pemerintahan dibedakan atas Pemerintah Kolonial dan Pemerintahan Pribumi. Dalam lingkup pemerintahan pribumi di Cirebon dibentuk tiga kabupaten yang dipimpin oleh tiga orang sultan di Cirebon dengan jabatan bupati dan sebagai Bupati-Wedana (bupati kepala) adalah Sultan Kasepuhan. Setiap kabupaten terdiri atas 4 distrik dan tiap distrik di kepalai oleh seorang tumenggung. Tumenggung berkedudukan di sebuah desa yang lokasinya terletak di tengah-tengah daerah distrik. Tempat kedudukan tumenggung menjadi ibukota (dayeuh) distrik tersebut.

Kepada setiap distrik diperbantukan 1 orang bupati luar (wakil bupati), 1 orang bupati dalam, 2 orang demang, 6 orang mantri, 10 orang jaksa, 10 orang penghulu kepala, dan 1 orang khatib. Jaksa dibantu oleh 8 orang jagabela, 1 orang sipir kepala, 1 orang wakil sipir, dan 4 orang upas. Khatib dibantu oleh 2 orang pembantu (Ekadjati, 2003:73)

Wilayah Prefektur Kesultanan Cirebon dibagi ke dalam 12 distrik, yaitu Losari, Gebang, Panjalu, Talaga, Kuningan, Cikaso, Matang Aji, Rajagaluh, Sindangkasih, Bengawan Wetan, Bengawan Kulon dan Paparean.

Dari 12 distrik di Prefektur Cirebon ada 2 distrik yang masuk ke dalam wilayah kabupaten Kuningan sekarang, yaitu Distrik Cikaso dan Distrik Kuningan. Kedua distrik tersebut berada di bawah pemerintahan Sultan Sepuh (Kasepuhan). Distrik Cikaso memiliki 547 jung sawah dan 9.488 cacah penduduk. Sesungguhnya 300 jung sawah di dalam Distrik Gebang 
bagian Selatan (tanah pegunungan) termasuk daerah Kuningan sekarang (Emran, 1978:53).

Dengan demikian telah ditetapkan bahwa secara politik para sultan di Cirebon (Kasepuhan, Kanoman, dan Kacirebonan) tidak memiliki kekuasaan lagi, karena kedudukan mereka diubah menjadi pegawai Pemerintah Kolonial Hindia Belanda. Sultan-sultan di Cirebon hanya berstatus simbol terhadap rakyatnya dan dapat dikatakan pegawai atau alat pemerintah kolonial. Situasi seperti itu membuat pemerintahan di Cirebon termasuk Kuningan menjadi terbengkalai. Pada tanggal 5 Januari 1819, dikeluarkan keputusan Komisaris Jenderal No. 23 untuk membentuk Kabupaten Kuningan, tetapi wilayah administrasinya baru meliputi bagian selatan wewengkon Kabupaten Kuningan yang sekarang. Selanjutnya pada tanggal 13 Maret 1909, ditetapkanlah wilayah Prefek Kesultanan Cirebon yang terbagi atas tiga daerah yang masing-masing dikepalai oleh salah seorang sultan sepuh, ketiga daerah tersebut adalah:

1. Daerah Cirebon dan Kuningan yang dikepalai oleh Sultan Sepuh ke-7, Pangeran Tajal Arifin Jihanuddin yang memerintah selama 25 tahun.

2. Daerah Majalengka, yang dikepalai oleh Sultan Anom ke-6, Pangeran Raja Mohammad Komarudin I yang memerintah selama 27 tahun.

3. Daerah Indramayu yang dikepalai oleh Sultan Kacirebonan yang memerintah selama 6 tahun

Daerah Kabupaten Kuningan yang sekarang sudah mengalami pengembangan, meliputi 5 wilayah pembangunan, yaitu:

1. Wilayah pembangunan Kuningan yang terdiri dari Kecamatan Kuningan, Garawangi, Ciniru, Jalaksana, dan Kramatmulya.

2. Wilayah pembangunan Kadugede, yang terdiri dari Kecamatan Kadugede, Darma, Selajambe, dan Subang.
3. Wilayah pembangunan Cilimus, yang terdiri dari Kecamatan Cilimus, dan Mandirancan.

4. Wilayah pembangunan Luragung, yang terdiri dari Kecamatan Luragung, Lebakwangi, dan Ciawigebang.

5. Wilayah pembangunan Cibingbin yang terdiri dari Kecamatan Cibingbin, dan Ciwaru (Sekwilda II Kuningan, 1989: 138).

Sejak tahun 1978 tanggal 1 September ditetapkan sebagai hari jadi Kabupaten Kuningan, dengan pertimbangan:

1. Peristiwa itu merupakan satu titik yang sampai sekarang masih dirasakan kelanjutan dan pengaruhnya oleh masyarakat Kuningan yang memberi dukungan aspirasi bagi kemajuan daerah ini.

2. Menggambarkan terbentuknya satuan masyarakat yang teratur yang telah memiliki pemerintahan sendiri.

3. Peristiwa itu mengandung nilai edukatif tinggi yang dapat mendorong semangat generasi berikutnya untuk membangun daerah Kuningan dalam lingkup pembangunan bangsa Indonesia secara keseluruhan sehingga hari jadi tersebut senantiasa menjadi semangat untuk kemajuan daerahnya.

Adapun nama-nama Kepala

Pemerintahan Kuningan sesuai masanya adalah:

\section{A. Zaman Hindu}

1. Seuweukarmn

2. Sanjaya

3. Rahiyang Tamperan

4. Rahiyang Banga

5. Rakean Darmasiksa

6. Arya Kamuning
B. Zaman Islam
1. Adipati Kuningan
2. Geusan Ulun
3. Dalem Mangkubumi 


\section{Zaman Penjajahan Belanda dan Jepang}

1. R. Brata Adiningrat

2. Doejeh Bratamidjaja

3. R. Dali Soerjanataatmadja

4. R. Moch. Achmad

5. R. Umar Said

\section{Zaman Kemerdekaan RI 1945}

R. Asyikin Nataatmadja

E. Zaman Kedudukan NICA (Recomba)

1. R. Asyikin Joedadibrata

2. R. Hollan Soemadiningrat

3. R. Abdul Rivai

F. Zaman RI 1950 - sekarang

1. R. Noer Atmadibrata (1945-19510)

2. R. Moch Hafil

3. R. Tikok M. Ichlas (1951-1952)

4. R. Soemitra (1952-1954)

5. TB. Amin Abdullah (1954-1957)

6. Yusuf (pejabat 1957-1958)

7. Saleh Alibasah

8. Usman Djatikusunah (1961-1966)

9. Rd. Komar Surjanataatmadja

10. R. Soemintaatmadja (1966-1967)

11. R. Aruman W. (1967-1973)

12. Karli Akbar (1973-1978)

13. R.H Unang S, S.H (1978-1983)

14. Drs. H. M. Jufri P (1983-1988)

15. Drs. H. Subandi

16. H. Yeng D.S.P

17. Drs. H. Arifin S, M.M (1998-2003)

18. H. Aang H. Suganda (2003-2008)

19. H. Aang H. Suganda (2008-2013)

20. Hj. Utje C. Suganda, S.Sos, M. AP (2013-sekarang)

(Bappeda Kab. Kuningan, 2013:2)

\section{Kehidupan Sosial-Budaya}

Manusia sepanjang hidupnya menerima waisan budaya yang diturunkan dari leluhurnya, juga menikmati hasil budaya yang tercipta selama dia hidup. Komposisi mengenai hal itu tentu saja berbeda antara kelompok masyarakat yang satu dengan yang lainnya. Ada kelompok masyarakat yang lebih banyak melaksanakan aktivitas budaya kekinian.
Dalam hal ini hanya sebagian kecil warisan budaya leluhur yang masih dipertahankan dan dilaksanakan oleh mereka. Oleh karena itu, kehidupan mereka sehari-hari cenderung sama dengan kelompok masyarakat lain pada umumnya (Adeng, 2014: 401).

Di wilayah Kuningan proses akulturasi budaya telah lama terjadi sehingga memengaruhi juga nilai-nilai sosial, misalnya dari sisi bahasa. Orang Kuningan dapat dikenali dari logat dan nada yang digunakan, jelas sekali adanya pengaruh dari Cirebon, Indramayu, dan Brebes (Jawa Tengah) meskipun masyarakat Kuningan pada umumnya memakai bahasa Sunda.

\section{a. Kesenian dan Upacara Tradisi Kuningan}

Di era globalisasi saat ini ketika pertukaran informasi dengan kebudayaan lain semakin gencar, beberapa upaya untuk menyaring pengaruh buruk dari budaya luar terus diupayakan meskipun terasa sangat sulit.

Salah satu upaya agar generasi sekarang dan mendatang tidak kehilangan jatidiri sebagai bangsa besar yang beradab adalah dengan membangun budaya kita dengan sungguh-sungguh agar bisa sejajar sekaligus pembendung bagi pengaruh buruk budaya luar.

Dalam hal adat istiadat Kabupaten Kuningan kaya dengan peristiwa budaya. Beberapa seni budaya yang masih terpelihara, yaitu: saptonan, drama wekwek, goong rendong, kuda lumping, tari buyung, kemprongan, dan cingcowong. Seni budaya tradisional ini tetap terbina dan dikembangkan melalui kegiatan pembinaan dan pergelaran-pergelaran.

Tari Buyung adalah salah satu tarian khas Kabupaten Kuningan yang selalu dipentaskan pada upacara Seren Taun di Cigugur. Tarian yang menggambarkan para gadis gunung yang sedang mengambil air merupakan kesenian turun temurun dengan latar belakang dari kebiasaan mengambil air dengan 
menggunakan buyung. Buyung adalah sejenis alat yang terbuat dari logam maupun tanah liat untuk mengambil air di sungai.

Setiap gerakan dalam Tari Buyung memiliki makna yang tersirat. Misalnya, menginjak kendi sambil membawa buyung di kepala (nyuhun) erat katannya dengan ungkapan "di mana bumi dipijak, di situ langit dijungjung". Membawa buyung di atas kepala sangat memerlukan keseimbangan. Hal ini berarti bahwa dalam kehidupan ini perlu adanya keseimbangan antara perasaan dan pikiran.

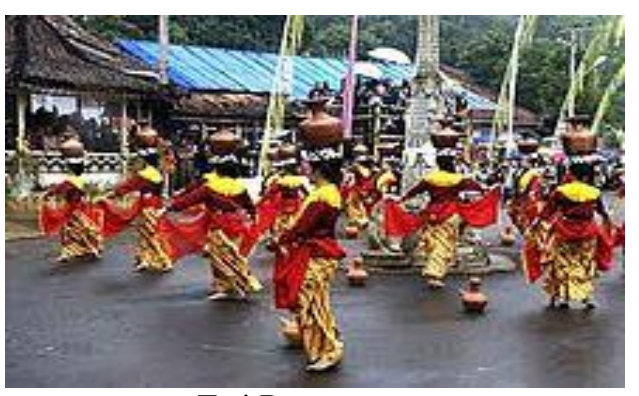

Tari Buyung

Sumber: Pemda Kab. Kuningan.

Tradisi Saptonan dan panahan di Kabupaten Kuningan memiliki daya tarik tersendiri dibandingkan tradisi lainnya. Biasanya dilaksanakan secara rutin setiap hari Sabtu setelah kegiatan serba raga yang dilaksanakan sekitar istana Kerajaan Kajene (Kuningan) dan mempunyai makna yang dalam seperti heroism, ketangkasan berkuda dan panahan dalam bela negara serta kebersamaan antara pemerintah dengan rakyatnya.

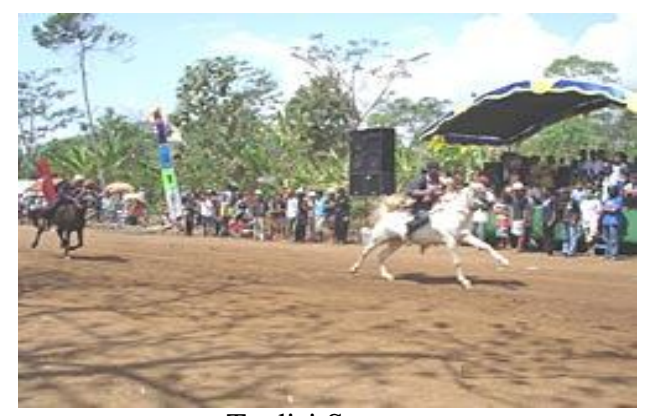

Tradisi Saptonan

Sumber: Pemda Kab. Kuningan.
Tradisi Saptonan pernah mengalami masa keemasan pada zaman kolonial. Namun, tradisi ini nyaris punah seandainya pihak Pemerintah Daerah dalam hal ini pihak Dinas Pariwisata dan Kebudayaan tidak melestarikannya. Untuk mengikuti tradisi ini banyak hal yang harus diperhatikan oleh peserta, di samping ketangkasan berkuda, kudanya pun harus pilihan yang mengerti terhadap bunyi gamelan. Pakaian yang dikenakan peserta saptonan beraneka ragam dan corak ada yang memakai pakaian raja, ponggawa, patih atau prajurit keraton yang memperlihatkan kesatriaan. Persyaratan pakaian ini setelah zaman kemerdekaan makin tidak mengikat, para peserta bebas mengenakan pakaian kampret, begitu juga dengan kudanya sudah tidak memakai atribut lagi, berbeda dengan dulu bagian kepala dan bagian belakang kudanya dihiasi oleh bulu-bulu merak.

Untuk tradisi Saptonan ini tidak sembarang orang bisa jadi peserta karena tradisi ini sengaja diciptakan untuk para lurah. Tetapi setelah penguasa Belanda meninggalkan Indonesia tradisi Saptonan bisa diikuti siapa saja yang berminat dan memiliki kuda.

Cingcowong merupakan tradisi warisan nenek moyang yang sejak sekitar 200 tahun silam sudah dilakukan secara turun-temurun. Tradisi Cingcowong adalah tradisi masyarakat Luragung Landeuh untuk memohon kepada Tuhan Yang Maha Esa, agar menurunkan hujan ketika musim kemarau panjang. Kesenian tradisional tersebut diwariskan secara turun menurun kepada keturunan asli Eyang Nata dan sekarang keturunan yang mewarisi kesenian tradisional tersebut keturunan yang ke-4 yaitu ibu Nawita (Adeng dkk, 2012:86).

Tradisi ini dalam visualisasinya berbau magis. Cingcowong terbuat dari bubu, sejenis alat untuk menangkap ikan dari anyaman bambu yang dibentuk seolah-olah mirip tubuh manusia, dan gayung dijadikan kepala atau mukanya. 
Peralatan yang dipergunakan untuk kesenian Cingcowong tersebut adalah sebagai berikut:

1. Bubu (dalam bahasa Sunda disebut buwu) yaitu alat untuk menangkap ikan atau perangkap ikan yang terbuat dari anyaman bambu yang digunakan sebagai badan Cingcowong.

2. Gayung (dalam bahasa Sunda di sebut siwur) sebagai kepalanya dan didandani sehingga menyerupai wajah wanita cantik, dalam ungkapan lain sebagai jelmaan wajah bidadari dan pakaian yang digunakan yaitu pakaian kebaya panjang sebagai sabuknya yaitu kain putih dan sebagai hiasan di leher atau kalung memakai bunga kamboja yang dirangkai. Khusus bunga kamboja harus diambil dari kuburan.

Alat-alat pengiring yang digunakan pada pagelaran Cingcowong di antaranya:

1. Jambangan yang terbuat dari kuningan (disebut dengan bokor), kuningan yang dipukul sebagai ketukan (disebut dengan cneng)

2. Tempayan (buyung) untuk pengatur irama yang dipukul dengan kipas yang terbuat dari anyaman bambu.

3. Tangga yang terbuat dari bambu yang berfungsi untuk membawa atau menyambut turunnya arwah lelembut atau dalam peribahasa untuk menyambut turunnya bidadari.

4. Tikar pandan atau tikar yang terbuat dari anyaman pandan yang biasa digunakan untuk alas orang yang meninggal dunia atau mayat, yang berfungsi sebagai alas tempat duduk pagelaran tersebut.

5. Ruas bambu yang dipukul-pukul untuk mengiringi irama.

Personil dalam acara tradisi tersebut berjumlah 10 orang, terdiri dari:

1. Satu orang pemukul jambangan atau bokor.

2. Satu orang penabuh tempayan.

3. Dua orang pembawa tangga.

4. Empat orang pembawa kain panjang.
5. Ibu Nawita sebagai pemeran utama, yang memegang penting dalam pagelaran Cingcowong.

6. Seorang kakek-kakek sebagai ketua adat atau dukun yang membawa kemenyan.

Biasanya pagelaran Cingcowong dilaksanakan pada malam Jumat sekitar pukul 17.00. Cingcowong disimpan di parit kecil atau comberan dengan mantra-mantra kemudian diisi dengan arwah penasaran yaitu arwah wanita yang tidak sempurna meninggalnya. Biasanya wanita yang meninggal karena bunuh diri atau meninggal yang tidak sempurna lainnya. Istilah untuk memanggil arwah ini disebut nyambat arwah bidadari.

Boneka Cingcowong dibawa oleh ibu Nawita sambil membacakan mantramantra. Tidak lama kemudian Cincowong secara gaib bergerak-gerak ke sana ke mari mengajak ke mana dia mau. Saat itulah Cingcowong harus disembur dengan air. Masyarakat yang menyaksikan di seputar arena harus spontan berteriak "hujan..hujan..hujan...". Tidak lama kemudian biasanya terdengar suara gemuruh dan hujan pun akhirnya turun.

Saat ini tradisi Cingcowong mulai jarang digelar apalagi bila intensitas hujan sedang tinggi. Kalaupun digelar tidak lagi sesakral dahulu, artinya bisa kapan saja digelar sesuai permintaan.

Upacara tradisi lainnya adalah Seren Taun di Cigugur yang dilaksanakan antara tanggal 18-22 Rayagung bulan Jawa, dipusatkan di Gedung Paseban Tri Panca Tunggal, yang kini menjadi Cagar Budaya Nasional sejak diresmikan pada 10 Oktober 1981.

Pembukaan diawali dengan acara "ngajayak" yang berarti "menyambut dan menerima" pada tanggal 18 Rayagung. Aneka ragam umbul-umbul, hiasan janur dan kelapa muda menambah semarak suasana. Padi yang sudah dikumpul sebanyak $2.200 \mathrm{~kg}$ setara 22 kwintal disimpan di tempat-tempat yang sudah ditentukan, yaitu di empat penjuru (Barat, Utara, Selatan, dan Timur). Pada tanggal 
18 Rayagung padi dari empat penjuru itu diangkat ke Gedung Paseban Tri Panca Tunggal.

Iringan pembawa padi pada saat ngajayak antara lain: rombongan pertama terdiri dari 11 pasang jejaka dan gadis, rombongan kedua adalah ibu-ibu yang membawa padi di atas kepala. Di belakang ibu-ibu adalah barisan kakek-kakek yang membawa padi dipikul pada pundaknya sambil berjalan. Para peserta upacara tradisi ini berangkat dari keempat jurusan menuju tempat upacara diiringi gamelan gong renteng, angklung buncis dan bunyibunyian dog-dog.

Penumbukan padi secara simbolis dilaksanakan oleh pejabat dan rohaniawan yang diiringi oleh gondang ibu-ibu. Selesai melakukan simbolis penumbukan para undangan kembali ke dalam ruangan upacara dan penumbukan dilanjutkan oleh peserta upacara sampai menjadi beras. Hasil penumbukan padi langsung dibagikan, $50 \%$ untuk para peserta, $50 \%$ untuk badan-badan sosial dan fakir miskin yang ada di Desa Cigugur.

Tradisi Ngaraya adalah suatu tradisi yang sampai saat ini masih dilakukan di pedesaan, khususnya di lingkungan Kabupaten Kuningan, yaitu tradisi nganjang atau bertamu menjelang lebaran. Saat ini tradisi ngaraya sudah mengalami perubahan dalam hal mengirim hidangan berupa makanan dan lauk pauk. Semula kiriman tersebut tidak menggunakan pemulang (jawaban menerima sajian), biasanya berupa uang atau pakaian. Apabila dikirim hidangan sekarang sudah menjadi kebiasaan untuk menyediakan pemulang, dengan uang yang besarnya lebih dari harga kiriman yang disajikan.

Sehari sebelum lebaran, pihak
keluarga perempuan menyiapkan bermacam-macam makanan dengan lauk pauknya, kemudian dikirim ke rumah si pemuda untuk disantap saat berbuka puasa. Dengan datangnya kiriman itu si pemuda tidak tinggal diam, ia akan membakar petasan yang telah disiapkan sebelumnya sebagai tanda penghormatan. Bunyi ledakan petasan adalah sebagai pertanda bahwa di rumahnya ada tunangan yang mengirim hidangan. Sementara itu suara bedug di masjid sejak menjelang sore sudah bertalu-talu, si pemuda sudah bersiap-siap dengan pakaian baru dan uang untuk diberikan kepada tunangannya sebagai tanda "mitrahan".

Tradisi ngaraya ini masih berkembang dan hidup di daerah pedesaan Kabupaten Kuningan. Namun ada penduduk desa yang menyederhanakan tradisi ini, misalnya menyalakan petasan ditiadakan karena dilarang oleh pihak berwajib, sedangkan tradisi lainnya disesuaikan dengan situasi dan kondisi saat ini.

\section{PENUTUP}

Seperti telah dipaparkan di atas bahwa Kabupaten Kuningan memiliki rentang sejarah yang panjang jika melihat jejak peradaban yang ada. Dimulai dari masa pra sejarah, masa Hindu, masa Islam, masa Kolonial, hingga masa kemerdekaan.

Masa prasejarah di wilayah Kuningan telah berkembang suatu kebudayaan yang dikenal dengan kebudayaan megalitik (batu besar) yang merupakan akar kebudayaan Indonesia pada zaman berikutnya. Peninggalanpeninggalannya ditemukan di kaki dan lereng Gunung Ciremai dan terdapat hampir di setiap kecamatan, mulai dari Kecamatan Mandirancan sampai Kecamatan Subang. Peninggalanpeninggalan tersebut berupa tanda-tanda kebudayaan yang menunjukkan perikehidupan masyarakat pada zaman purbakala yang tingkat kebudayaannya sudah mencapai relatif tinggi. Sebagai contoh terdapat di daerah Cipari, Desa Cigugur yang sekarang telah dibangun Taman Purbakala sebagai salah satu bentuk rekontruksi keadaan pemukiman masyarakat manusia berkebudayaan pada zaman purbakala.

Untuk masalah pendidikan, pada masa kolonial sekolah yang pertama 
didirikan oleh Pemerintah Hindia Belanda untuk pribumi di Kuningan adalah Sekolah Kelas Satu (Eerste Klasse Inlandsche School) pada akhir abad ke-19. Kemudian pada tahun 1905 didirikan Sekolah Kelas Dua di Kota Kuningan. Setahun kemudian di Kadugede, Cilimus, Ciawigebang, Luragung, dan Mandirancan.

Kabupaten Kuningan secara umum memiliki kekayaan budaya yang tidak kalah dengan wilayah lainnya yang ada di Jawa Barat, di antaranya ada Tradisi Saptonan yang merupakan tradisi sejak masa kolonial, Cingcowong, Tari Buyung, Upacara Kawin Cai, Seren Taun, dan sebagainya. Masyarakat Kabupaten Kuningan pun telah sejak lama menerapkan pendekatan multikultural sehingga masyarakatnya sudah terbiasa hidup dalam perbedaan. Dalam lingkup kecil, di wilayah Kecamatan Cigugur misalnya, dalam satu keluarga ada yang beragama Islam, ada yang beragama Kristen, dan ada yang menganut Kepercayaan Terhadap Tuhan Yang Maha Esa tetapi mereka tetap rukun tanpa sedikitpun menimbulkan konflik. Tingkat toleransi yang tinggi menimbulkan sikap yang saling menghargai.

Lintasan transportasi di Kabupaten Kuningan yang multi arah memberikan dampak positif karena secara teritorial cukup terbuka untuk kehidupan sosialbudaya yang berasal dari kawasan sekitarnya.

\section{UCAPAN TERIMA KASIH}

Penulis mengucapkan terima kasih kepada Bapak Suyono, selaku sesepuh di Kuningan yang telah memberi informasi mengenai sejarah dan kebudayaan Kabupaten Kuningan, juga Bapak Yosef selaku Kabid Kebudayaan Disbudpar Kabupaten Kuningan dan semua pihak yang telah memberikan bantuan pada saat penelitian tersebut.

\section{DAFTAR SUMBER}

\section{Skripsi}

Sulistiyani, Yeni. 2011.

Kehidupan Sosial Ekonomi Masyarakat Cina Benteng Pada Masa Orde Baru (1966-1998), Skripsi, Bandung: UPI.

\section{Jurnal}

Adeng.. "Sejarah Sosial Kota Bekasi", dalam Patanjala Vol. 6 No. 3, September 2014, hlm. 397-412.

\section{Buku}

Adeng dkk. 2012

Cingcowong, Upacara Meminta Hujan pada Masyarakat Kuningan. Bandung: BPNB Bandung.

Atja.1968.

Tjarita Parahiyangan. Bandung: Jajasan Kebudayaan Nusalarang.

Atja. 1975.

Sejarah Jawa Barat: dari Prasejarah Hingga Penyebaran Agama Islam. Bandung Proyek Penunjang Kebudayaan Nasional Pemerintah Jawa Barat.

Badan Pusat Statistik Kuningan, 2000.

Kuningan dalam Angka 2000, Kuningan: BPS.

Badan Pusat Statistik Kuningan, 2012.

Kuningan dalam Angka 2012, Kuningan: BPS.

Bappeda Kab. Kuningan, 2013.

Kabupaten Kuningan Jewel on the East, Kuningan: Bappeda.

Ekadjati, Edi S. 1975.

Penyebaran Agama Islam di Jawa Barat, dalam Sejarah Jawa Barat dan Masa Prasejarah hingga Masa Penyebaran agama Islam, Proyek Penunjang Peninggalan Kebudayaan Nasional Propinsi Jawa Barat.

Ekadjati, Edi S. 2003.

Sejarah Kuningan. Bandung: Kiblat

Emran, Ali 1978.

Sejarah dan Hari Jadi Kota Kuningan, Pemda Kabupaten Kuningan. 
Kuntowijoyo. 1999.

Metodologi Sejarah, Yogyakarta:

Tiara Wacana Yogya.

Mutakin, Awan. 2005.

Nilai-nila Kearifan Adat dan Tradisi

Di Balik Simbol Kuda Kuningan, Kuningan.

Pemda Kuningan, 2000.

Kuningan Menembus Waktu, Kuningan: Humas Pemda.

Rostiyati, Ani. 2008.

Peta Kebudayaan Indonesia Kabupaten Kuningan, Provinsi Jawa Barat, Bandung: BKSNT Bandung.

Sulendraningrat. P. S. Tt.

Sejarah Cirebon, Lembaga Kebudayaan 3 Cirebon, Keprabonan 47 Lemah Wungkuk, Cirebon.

Sulendraningrat. Tt.

Purwaka Cirebon Nagari Lembaga Kebudayaan 3 Cirebon, tanpa tahun.

Sulendraningrat. Tt.

Sejarah Cirebon dan Silsilah Sunan Gunung Jati Maulana Syarit Hidayatullah, Lembaga Kebudayaan Wil 3 Cirebon.

Thresnawaty, Euis. 1995

Peninggalan Sejarah Sebagai Objek Wisata di Kabupaten Kuningan. Bandung: BKSNT

\section{Wawancara}

Juhaeni, 28 Oktober 2012.

Dede Nono Rukmana, 28 Oktober 2012.

Suyono, 30 Oktober 2012.

\section{Internet}

http://mazjoe.blogdetik.com/2009/09/27/11/ Cingcowong Kabupaten Kuningan. Diakses 14 September 2014

https://aditya69.wordpress.com/2007/10/27/san g-adipati-kuningan-adalah-putraluragung/ diakses 16 Desember 2015 